\title{
Synthesis, DNA Interaction and Genotoxic Evaluation of a Photoactive Benzothiadiazole with Potential Application in Photovoltaic Paint
}

\author{
Adriani P. Damiani, ${ }^{a}$ Paula Rohr, ${ }^{a}$ José L. Westrup, ${ }^{b}$ Rodrigo C. Duarte, ${ }^{c}$ \\ Luiza M. Longaretti, ${ }^{a}$ Bruna M. da Rocha, ${ }^{a}$ Giulia Strapazzon, ${ }^{a}$ Lara C. Venturini, ${ }^{a}$ \\ Emanuel Souza, ${ }^{a}$ Claus T. Pich, ${ }^{d}$ Tiago E. A. Frizon, ${ }^{b}$ Vanessa M. de Andrade, ${ }^{a}$ \\ Fabiano S. Rodembusch ${ }^{*, c}$ and Alexandre G. Dal-Bó ${ }^{*, b}$
}

${ }^{a}$ Laboratório de Biologia Celular e Molecular, Programa de Pós-Graduação em Ciências da Saúde, Unidade Acadêmica de Ciências da Saúde, Universidade do Extremo Sul Catarinense, Av. Universitária, 1105, 88806-000 Criciúma-SC, Brazil

${ }^{\text {b} P r o g r a m a ~ d e ~ P o ́ s-G r a d u a c ̧ a ̃ o ~ e m ~ C i e ̂ n c i a ~ e ~ E n g e n h a r i a ~ d e ~ M a t e r i a i s, ~ U n i v e r s i d a d e ~ d o ~ E x t r e m o ~ S u l ~ C a t a r i n e n s e, ~}$ Av. Universitária, 1105, 88806-000 Criciúma-SC, Brazil

${ }^{c}$ Grupo de Pesquisa em Fotoquímica Orgânica Aplicada, Instituto de Química, Universidade Federal do Rio Grande do Sul, Avenida Bento Gonçalves, 9500, 91501-970 Porto Alegre-RS, Brazil

${ }^{d}$ Centro de Biologia Molecular Estrutural (CEBIME), Universidade Federal de Santa Catarina (UFSC), Campus Trindade, 88040-900 Florianópolis-SC, Brazil

\begin{abstract}
A new fluorophore containing 2,1,3-benzothiadiazole unit with alkylated tetrazole terminal groups as electron donors connected through a $\pi$-conjugated system of the type (D- $\pi$-A- $\pi$-D) was synthesized using the Sonogashira coupling reaction with good yields. The genotoxicity of the two intermediate compounds and the final product was evaluated in vitro in consideration of the potential application of the new compound in the chemical production of photovoltaic paints. The new fluorophore did not show significant biological effects in the cell viability test and the comet assay when compared with the intermediate compounds that were obtained synthetically despite the ability to interact with deoxyribonucleic acid (DNA) as demonstrated in circular dichroism assays. Thus, the compound does not show toxic or genotoxic activity, and therefore, it can be applied as a pigment in photovoltaic paint.
\end{abstract}

Keywords: cell viability, genotoxicity, mutagenicity, photovoltaic paint, circular dichroism

\section{Introduction}

Interest in the application of organic compounds in optoelectronic devices is currently increasing. ${ }^{1}$ These compounds have been extensively investigated since they could lead to smaller devices that are more flexible and of lower cost. Examples of these applications include organic photovoltaic cells (OPVs), ${ }^{1-8}$ organic light-emitting diodes (OLEDs), ${ }^{9-12}$ organic field effect transistors (OFETs), ${ }^{3}$ organic thin film transistors (OTFTs) ${ }^{13-18}$ and organic solar cells. ${ }^{19,20}$ In this sense, different polymers, small molecules, oligomers and hybrid compounds have been investigated for optoelectronic applications. ${ }^{21}$

In this context, compounds that contain the electron

*e-mail: adalbo@unesc.net; fabiano.rodembusch@ufrgs.br acceptor 2,1,3-benzothiadiazole as the central unit bound to electron donors ${ }^{22-29}$ are of great interest for the development of photovoltaic devices because of their potential use in the production of flexible polymeric films ${ }^{30}$ that can be processed on a large scale. In addition, these $\pi$-conjugated compounds exhibit good intramolecular charge transfer, thereby reducing the band gap, ${ }^{3,18,31}$ which is a requirement for the application of these derivatives as pigments in photovoltaic paints. ${ }^{32}$ However, there is a lack of information regarding their interaction with deoxyribonucleic acid (DNA) and the in vitro toxicity and genotoxicity associated with the composition and chemical structures of intermediates and final compounds containing the 2,1,3-benzothiadiazole core. These have biological applications in fungicidal formulations as chemical activators of plant resistance. Since paints are composed of a mixture of several components, they can 
generate reactive oxygen species (ROS) which can damage biomolecules and increase the health risks to exposed operators. ${ }^{33-37}$ The interaction with and damage to DNA can alter cellular metabolism and genomic stability. ${ }^{35}$ The evaluation of DNA interactions can be performed by several methods, and circular dichroism (CD) is a well-established method for this purpose. ${ }^{36} \mathrm{CD}$ can detect alterations in the optical activity of chiral molecules by their interaction with circularly polarized electromagnetic rays. The B-form conformation of calf thymus-DNA (CT-DNA) produces two CD bands in the UV region, a positive band at $278 \mathrm{~nm}$ due to base stacking and a negative band at $246 \mathrm{~nm}$ due to polynucleotide helicity. The genetic damage that is caused by exposure to compounds with different chemical, physical and biological characteristics can be evaluated using genotoxicity biomarkers, which play an important role in the prediction of health risks, ${ }^{37,38}$ as is used in the comet assay. ${ }^{39}$ This test allows the direct measurement of single- and double stranded DNA breaks, alkali-labile sites, crosslinking of DNA and incomplete excision repair sites..$^{40}$ In addition, the cell viability test is also an important tool for studying genetic damage and for detecting non-viable cells that have damaged membranes that affect cellular adhesion or lead to cell death. ${ }^{41}$

Here, we report the DNA interaction and in vitro toxicity and genotoxicity of a photoactive compound and respective intermediates that contain alkylated tetrazole rings as electron donor groups bound by a $\pi$-conjugated system to a 2,1,3-benzothiadiazole group as an electron donor unit. These compounds have potential applications in photovoltaic paints, devices and electronic systems.

\section{Experimental}

\section{Materials and methods}

All reagents and solvents were purchased from commercial suppliers and were used without further purification. The solvents were dried and distilled before use based on procedures available in the literature. ${ }^{42}$ The melting point was measured using a Thermolyne apparatus and was uncorrected. The vibrational spectra of the intermediates and the final compound in $\mathrm{KBr}$ pellets were obtained using a Shimadzu IR Prestige 21 with a resolution of $4 \mathrm{~cm}^{-1}$ between 400 and $4000 \mathrm{~cm}^{-1}$. The ${ }^{1} \mathrm{H}$ and ${ }^{13} \mathrm{C}$ nuclear magnetic resonance (NMR) spectra were obtained in $\mathrm{CDCl}_{3}$ at 400 and $100 \mathrm{MHz}$, respectively. The chemical shifts $(\delta)$ are reported in parts per million (ppm) relative to tetramethylsilane (TMS) $(0.00 \mathrm{ppm})$, and the coupling constants $(J)$ are reported in hertz $(\mathrm{Hz})$. The photostability was evaluated by UV-Vis absorption spectra in film on a Shimadzu UV-2450 spectrophotometer using an
ISR-2200 Integrating Sphere Attachment in a spectral range of 250-600 nm. The baseline was obtained using $\mathrm{BaSO}_{4}$ (Wako Pure Chemical Industries, Ltd.). Steady state fluorescence spectra was performed on a Shimadzu spectrofluorometer model RF-5301PC with a solid state holder. The experiments were performed at room temperature.

\section{5-(4-Bromophenyl)tetrazole (1)}

Yellow-colored crystals; mp 259-260 ${ }^{\circ} \mathrm{C} ;{ }^{43,44}$ FTIR (Fourier transform infrared spectroscopy) $(\mathrm{KBr}) \mathrm{v}_{\max } / \mathrm{cm}^{-1}$ 3444, 3086, 3061, 3000, 1900, 1602; ESI anal. calcd. for $\mathrm{C}_{7} \mathrm{H}_{5} \mathrm{BrN}_{4}: m / z$ 226.9, found: $246.9[\mathrm{M}+\mathrm{Na}]^{+}$.

\section{5-(4-Bromophenyl)-2-dodecanetetrazole (2)}

White solid; mp 54-55 ${ }^{\circ} \mathrm{C}$; FTIR (KBr) $v_{\max } / \mathrm{cm}^{-1} 2954$, 2918, 2848, 1602; ${ }^{1} \mathrm{H}$ NMR (400 MHz, $\mathrm{CDCl}_{3}$ ) $\delta 8.02$ (d, 2H, J $8.60 \mathrm{~Hz}), 7.62(\mathrm{~d}, 2 \mathrm{H}, J 8.21 \mathrm{~Hz}), 4.62(\mathrm{t}, 2 \mathrm{H}$, J 7.03 Hz), 2.10-1.95 (m, 2H), 1.45-1.30 (m, 2H), 1.30-1.15 $(\mathrm{m}, 16 \mathrm{H}), 0.87$ (t, 3H, J 6.64 Hz); ${ }^{13} \mathrm{C} \mathrm{NMR} \mathrm{(400} \mathrm{MHz,}$ $\left.\mathrm{CDCl}_{3}\right) \delta 156.8,124.8,120.9,119.2,117.2,46.0,24.6$, 22.3, 22.0, 21.5, 19.0, 15.3, 6.8 .

5-[4-(2-Methyl-3-butyne-2-ol-phenyl)]-2-dodecanetetrazole (3)

mp 64-65 ${ }^{\circ} \mathrm{C}$; FTIR (KBr) $v_{\max } / \mathrm{cm}^{-1} 3313,3055,2958$, 2920, 2850; ${ }^{1} \mathrm{H}$ NMR (400 MHz, $\mathrm{CDCl}_{3}$ ) $\delta 8.09$ (d, 2H, $J 8.20 \mathrm{~Hz}), 7.52(\mathrm{~d}, 2 \mathrm{H}, J 8.20 \mathrm{~Hz}), 4.64(\mathrm{t}, 2 \mathrm{H}, J 7.03$ and $7.32 \mathrm{~Hz}$ ), 2.55 (s, 1H), 2.06 (q, 2H, J $7.03 \mathrm{~Hz}), 1.65$ (s, $6 \mathrm{H}), 1.45-1.32(\mathrm{~m}, 2 \mathrm{H}), 1.32-1.22(\mathrm{~m}, 16 \mathrm{H}), 0.89(\mathrm{t}, 3 \mathrm{H}$, $J 6.59 \mathrm{~Hz}) ;{ }^{13} \mathrm{C} \mathrm{NMR}\left(400 \mathrm{MHz}, \mathrm{CDCl}_{3}\right) \delta 164.9,164.4$, $132.1,127.1,126.6,124.6,95.5,81.6,65.5,53.3,31.9$, $31.4,29.5,29.3,28.8,26.3,22.6,14.1$.

\section{1-Dodecanetetrazole-4-ethinylbenzene (4)}

mp 56-57 ${ }^{\circ} \mathrm{C}$; FTIR (KBr) $v_{\max } / \mathrm{cm}^{-1} 3286,2954,2916$, 2846; ${ }^{1} \mathrm{H} \mathrm{NMR}\left(400 \mathrm{MHz}, \mathrm{CDCl}_{3}\right) \delta 8.10(\mathrm{~d}, 2 \mathrm{H}, J 8.22 \mathrm{~Hz})$, 7.59 (d, 2H, J $8.22 \mathrm{~Hz}), 4.63(\mathrm{t}, 2 \mathrm{H}, J 7.04 \mathrm{~Hz}), 3.18$ (s, 1H), 2.04 (q, 2H, J 7.04 Hz), 1.40-1.30 (m, 2H), 1.30-1.17 $(\mathrm{m}, 16 \mathrm{H}), 0.86(\mathrm{t}, 3 \mathrm{H}, J 6.46 \mathrm{~Hz}) ;{ }^{13} \mathrm{C} \mathrm{NMR}(400 \mathrm{MHz}$, $\left.\mathrm{CDCl}_{3}\right) \delta 164.3,132.5,127.7,126.6,123.9,83.1,78.8,53.2$, 31.8, 29.5, 29.3, 28.8, 26.3, 22.6, 14.1; ESI anal. calcd. for $\mathrm{C}_{21} \mathrm{H}_{30} \mathrm{~N}_{4}: m / z$ 338.2, found: $361.3[\mathrm{M}+\mathrm{Na}]^{+}$.

\section{2,1,3-Benzothiadiazole (5)}

mp 43-44 ${ }^{\circ} \mathrm{C} ;{ }^{45}$ FTIR (KBr) $v_{\max } / \mathrm{cm}^{-1} 3088,3053$, 1613; ${ }^{1} \mathrm{H}$ NMR $\left(400 \mathrm{MHz}, \mathrm{CDCl}_{3}\right) \delta 7.97$ (dd, 2H, J 3.13 and $6.64 \mathrm{~Hz}), 7.56(\mathrm{dd}, 2 \mathrm{H}, J 3.13,7.03 \mathrm{~Hz}) ;{ }^{13} \mathrm{C} \mathrm{NMR}$ $\left(400 \mathrm{MHz}, \mathrm{CDCl}_{3}\right) \delta 154.7,129.2,121.5$.

\section{4,7-Dibromo-2,1,3-benzothiadiazole (6)} mp 187-188 ${ }^{\circ} \mathrm{C} ;{ }^{45}$ FTIR (KBr) $v_{\max } / \mathrm{cm}^{-1} 3078,3045$, 
1634; ${ }^{1} \mathrm{H}$ NMR (400 MHz, $\left.\mathrm{CDCl}_{3}\right) \delta 7.71(\mathrm{~s}, 2 \mathrm{H}) ;{ }^{13} \mathrm{C} \mathrm{NMR}$ (400 MHz, $\left.\mathrm{CDCl}_{3}\right) \delta 152.9,132.3,113.8$.

4,7-bis(1-Dodecanetetrazole-4-ethynylbenzene)2,1,3-benzothiadiazole (7)

Yellow solid; yield 95\%; mp 216-218 ${ }^{\circ} \mathrm{C}$; FTIR (KBr) $v_{\max } / \mathrm{cm}^{-1} 3037,2953,2920,2848,2204 ;{ }^{1} \mathrm{H}$ NMR $\left(400 \mathrm{MHz}, \mathrm{CDCl}_{3}\right) \delta 8.21$ (d, 4H, J 8.20 Hz), $7.85(\mathrm{~s}, 2 \mathrm{H})$, $7.82(\mathrm{~d}, 4 \mathrm{H}, J 8.20 \mathrm{~Hz}$ ), 4.68 (t, $4 \mathrm{H}, J 7.03 \mathrm{~Hz}$ ), 2.25-2.00 $(\mathrm{m}, 4 \mathrm{H}), 1.55-1.35(\mathrm{~m}, 4 \mathrm{H}), 1.35-1.15(\mathrm{~m}, 32 \mathrm{H}), 0.86(\mathrm{t}, 6 \mathrm{H}$, $J 6.44 \mathrm{~Hz}) ;{ }^{13} \mathrm{C}$ NMR $\left(400 \mathrm{MHz}, \mathrm{CDCl}_{3}\right) \delta 164.3,154.3$, 132.6, 132.4, 127.9, 126.7, 124.2, 117.1, 97.0, 86.8, 53.3, $46.0,31.8,29.5,29.4,28.8,22.6,14.1,8.6$.

\section{Photostability}

The photostability of compound $\mathbf{7}$ was studied in film, which were prepared by spin coating under vacuum using a Glove Box MBRAUN, model MB 200B with glass plates as substrates. The compound $\mathbf{7}$ was dissolved in chloroform and deposited onto glass substrate via the spin-coating method at $100 \mathrm{rpm}$ for $20 \mathrm{~s}$. The films were analyzed in UV radiation chamber, equipped with a cooling device, six Philips bulbs (model Actinic BL) were used, which emitted UVA radiation at a wavelength of $330 \mathrm{~nm}$, with a radiation intensity of $2.01 \mathrm{~mW} \mathrm{~cm}{ }^{-2}$. The radiation measurements were recorded in the chambers with a digital UV measurement device manufactured by Instrutherm (model MRUR-202). The chamber with six bulbs reproduced artificially an $824 \%$ incidence of UV-A.

\section{Circular dichroism}

The experiments were performed as described in the literature ${ }^{46}$ with small modifications using a JASCO 510 instrument. One sample of CT-DNA in $10 \mathrm{mM}$ 4-(2-hydroxyethyl)-1-piperazineethanesulfonic acid (HEPES) buffer was titrated with the complex using concentrations ranging from 19.80 to $181.82 \mathrm{mM}$ (molar ratios of 0.25 to 2.50 ) and 0 (negative control). The screenings were recorded from 240 to $400 \mathrm{~nm}$ at $37^{\circ} \mathrm{C}$ immediately after the addition of the complexes. The results were plotted and graphics presenting the regions of major interest were produced. Spectra containing only the complexes and DNA with increasing concentrations of solvent (dimethyl sulfoxide, DMSO) were collected as control reactions.

\section{Biological assays}

For the biological assays, different concentrations were prepared from a stock solution containing $20 \mathrm{mg}$ of each compound to be evaluated when diluted in $1 \mathrm{~mL}$ of DMSO. Three different amounts of stock solution were used: 100, 50 and $25 \mu \mathrm{L}$, containing 2,1 and $0.5 \mathrm{mg}$, respectively, of each compound.

\section{In vitro tests}

In this experiment $4 \mathrm{~mL}$ of peripheral blood was collected from 5 healthy volunteer subjects using disposable sterile materials to minimize the risk of infection and disease transmission. Blood samples were collected in Falcon tubes (1 mL per tube) containing heparin and were divided into four groups according to the exposure concentration to be evaluated. The blood was stored in a $\mathrm{CO}_{2}$ incubator at $37^{\circ} \mathrm{C}$ and samples were collected after 2, 6, 12 and $24 \mathrm{~h}$ of exposure to the compounds for the cell viability test and comet assay. All procedures were approved by the Ethics Committee in Research of the Universidade do Extremo Sul Catarinense under report No. 365397.

\section{Cell viability (trypan blue exclusion test)}

In this experiment $5 \mu \mathrm{L}$ of cell suspension and $5 \mu \mathrm{L}$ of trypan blue solution were mixed in a microtube. After mixing, the suspension was transferred to a Neubauer micro-camera and enclosed with a cover slip. A total of 100 cells were evaluated using an optical microscope at a magnification of $400 \times$ to determine the percentage of viable cells. ${ }^{47}$

\section{Comet assay}

The comet assays were performed under alkaline conditions as previously described by Tice et al. ${ }^{48}$ Peripheral blood samples were collected in heparinised tubes and were subsequently maintained on ice. Aliquots $(5 \mu \mathrm{L})$ of the blood cells were embedded in low melting point agarose $(0.75 \%, \mathrm{~m} / \mathrm{v} ; 95 \mu \mathrm{L})$. This mixture was then placed on a microscope slide that was pre-coated with normal melting point agarose $(1.5 \%, \mathrm{~m} / \mathrm{v})$ and furnished with a cover slip (two slides per sample). The slides were briefly placed on ice to enable the agarose to solidify and the cover slips to be removed carefully. The base slide was then immersed in freshly prepared lysis solution $(2.5 \mathrm{M} \mathrm{NaCl}, 100 \mathrm{mM}$ ethylenediaminetetraacetic acid-EDTA, $10 \mathrm{mM}$ Tris, pH 10.0-10.5). In the next step, the slides were immersed for $20 \mathrm{~min}$ in freshly prepared alkaline buffer (300 mM NaOH, 1 mM EDTA, pH > 13) for electrophoresis analysis (15 min per $300 \mathrm{~mA}, 25 \mathrm{~V}$, 
$\left.0.7 \mathrm{~V} \mathrm{~cm}^{-1}\right)$. These steps were performed under minimal indirect light. Following electrophoresis the slides were neutralized with $400 \mathrm{mM}$ Tris (pH 7.5) and stained with silver nitrate. To calculate the damage index (DI), cells were visually separated into five classes according to tail size $(0=$ no tails to 4 = maximum-length tails). Accordingly, a single DNA damage score was obtained for each sample and subsequently for each group studied. The DI for the group ranged from 0 (completely undamaged $=100$ cells $\times 0$ ) to 400 (maximum damage $=100$ cells $\times 4)$. The damage frequency (DF in percentage) was calculated for each sample based on the number of cells with tails compared to the number without tails. Visual scoring in the comet assay is considered a reliable method of evaluation and usually results in high correlation values with computer-based image analysis methods. ${ }^{49}$ All slides were coded and analyzed blind.

\section{Statistical analysis}

The normality of the variables was assessed using the Kolmogorov-Smirnov test. Statistical analysis of the values obtained for the damage index and damage frequency in the comet assay and the percentage of viable cells assessed in the cell viability tests was conducted by one-way analysis of variance (one-way ANOVA) and two-way analysis of variance (two-way ANOVA). The post hoc Bonferroni test was applied to results which exhibited significant differences. A $p$ value of $<0.05$ was considered statistically significant. The statistical package used was Prism 5.0. ${ }^{50}$

\section{Results and Discussion}

\section{Synthesis and spectroscopic characterization}

The benzothiadiazole compound $\mathbf{7}$ was obtained using a previously described ${ }^{51}$ synthetic method by reacting the 4,7-dibromo-2,1,3-benzothiadiazole (6) with the terminal alkyne 4 in a Sonogashira coupling reaction (Scheme 1).

Figure 1 shows the infrared absorption spectra for the precursors (3-4) and the final compound (7). Significant structural changes are observed that corroborate the proposed chemical structure of the studied compounds.

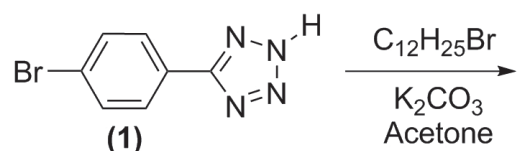

(1) Acetone<smiles>CCCNn1nnc(-c2ccc(Br)cc2)n1</smiles>

(2, 79\%)

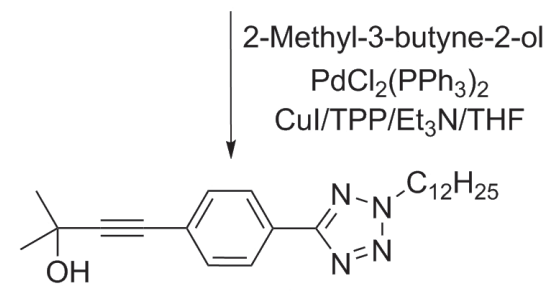

(3, 96\%)

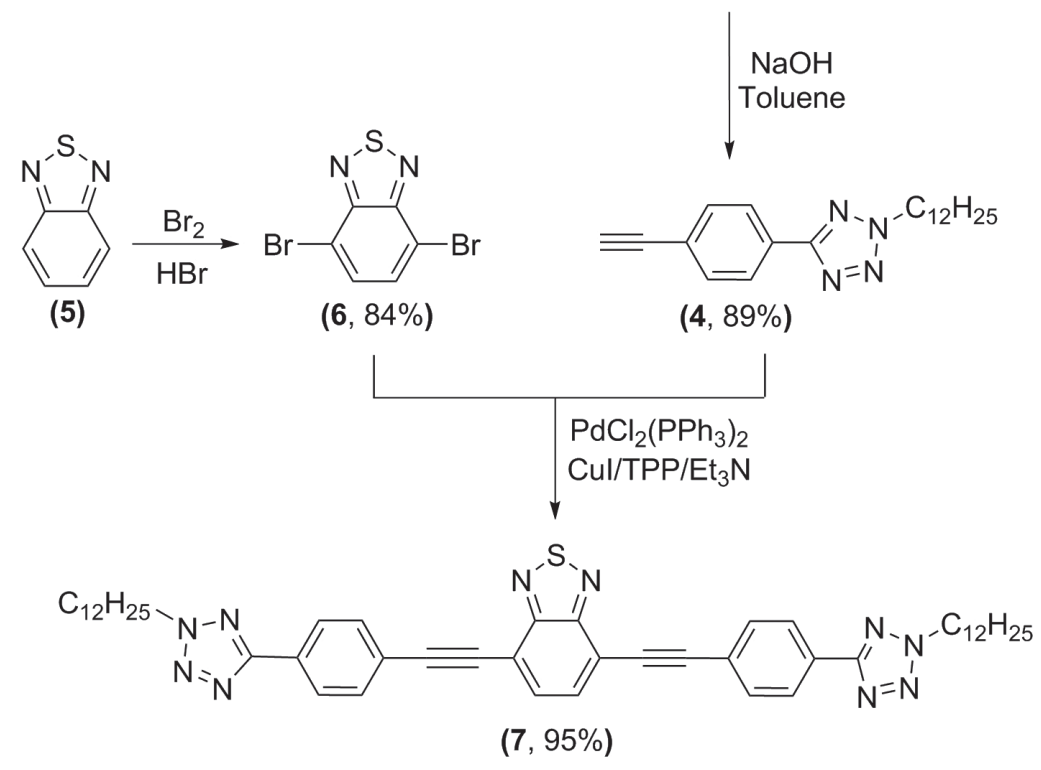

Scheme 1. Synthetic route used to produce benzothiadiazole (7)..$^{51}$ 
A vibrational mode that is due to aliphatic stretching bands of the $\mathrm{C}_{12} \mathrm{H}_{25}$ moieties is present for all compounds and is indicative of alkyl chains bound to the tetrazole ring. For compound 3, the stretching band of the $\mathrm{OH}$ group is located at $3310 \mathrm{~cm}^{-1}$, indicating a coupling between the aryl bromide 3 and 2-methyl-3-butyne-2-ol. An alkyne deprotection reaction was evidenced by the appearance of a $\mathrm{C}-\mathrm{H}$ stretching band of the terminal alkyne located at $3286 \mathrm{~cm}^{-1}$. In addition, a weak band located at $2204 \mathrm{~cm}^{-1}$ due to $\mathrm{C} \equiv \mathrm{C}$ stretching of the internal alkyne can be observed for compound 7.

In the ${ }^{1} \mathrm{H}$ NMR spectrum for compound 7 (Figure 2) there are eight signals, where two sets of equivalent hydrogens of the aromatic system (named a and b) at $8.21 \mathrm{ppm}(\mathrm{d}, 4 \mathrm{H}, J 9.00 \mathrm{~Hz})$ and $7.82 \mathrm{ppm}(\mathrm{d}, 4 \mathrm{H}$, $J 9.00 \mathrm{~Hz}$ ), respectively, correspond to a system of type $\mathrm{A}_{4} \mathrm{X}_{4}$. The singlet located at $7.85 \mathrm{ppm}$ related to $2 \mathrm{H}$, named (f) refers to the equivalent hydrogens of the benzothiadiazole central unit. In the region of the aliphatic hydrogens, three sets of signals are shown. The first one, a triplet located at $4.68 \mathrm{ppm}(4 \mathrm{H}, J 7.03 \mathrm{~Hz})$ named (c), corresponds to the methylene group directly bonded to the tetrazole ring. The second set of signals, a multiplet integrating $40 \mathrm{H}$ can be observed between 2.25 and $1.15 \mathrm{ppm}$ (named d) is due to the rest of the methylene chain; and the last one, a triplet

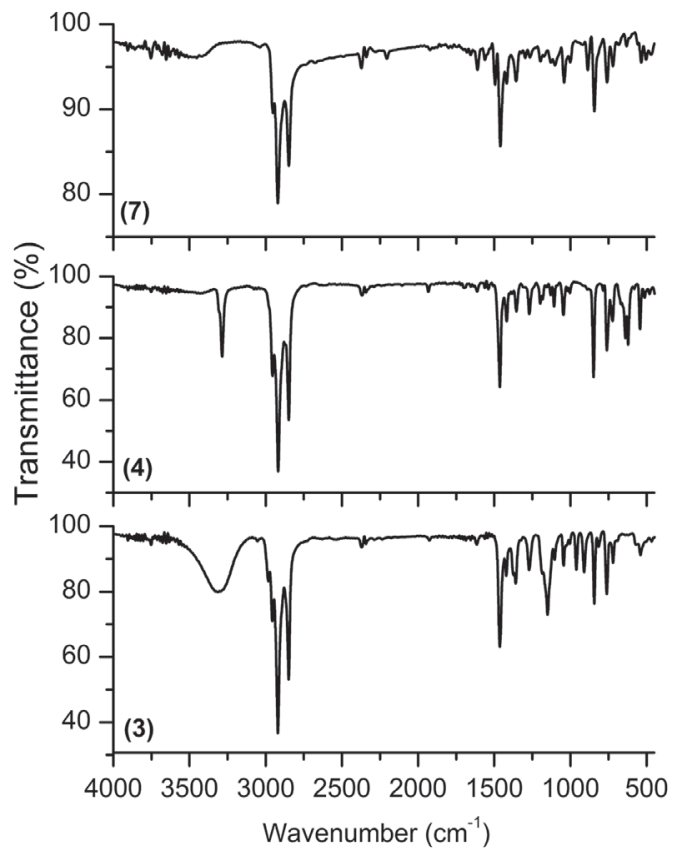

Figure 1. FTIR spectra $\left(500-4000 \mathrm{~cm}^{-1}\right)$ for compounds $\mathbf{3 , 4}$ and $\mathbf{7}$.

located at $0.86 \mathrm{ppm}(6 \mathrm{H}, J 6.44 \mathrm{~Hz})$, named (e) corresponds to the terminal methyl group.

In relation to the thermal stability of the compound 7 , it is worth mentioning that as reported in the literature, ${ }^{51}$
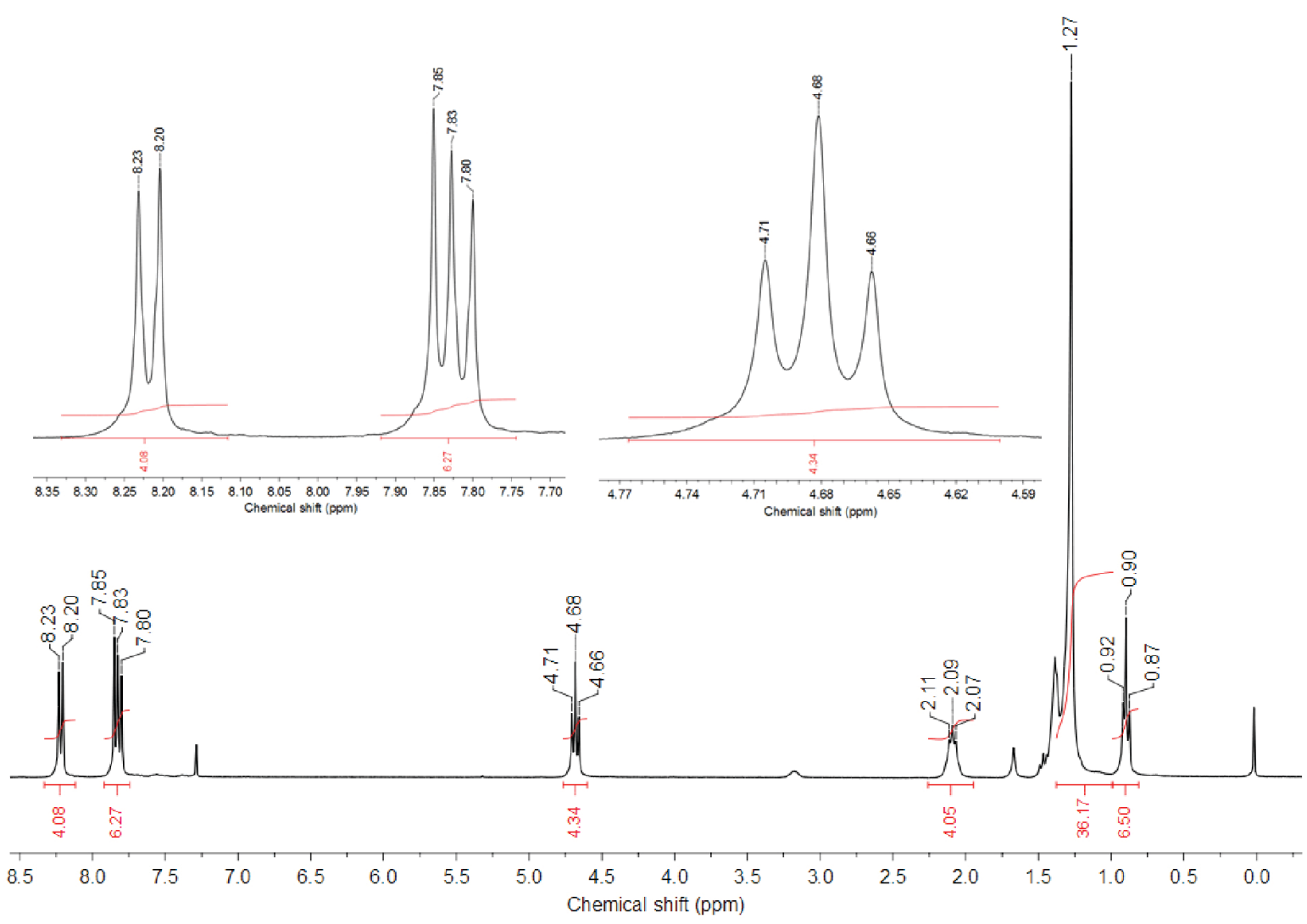

Figure 2. ${ }^{1} \mathrm{H}$ NMR spectrum of compound $7\left(\mathrm{CDCl}_{3}, 400 \mathrm{MHz}\right)$. The aromatic and part of the aliphatic regions are shown in zoom. 

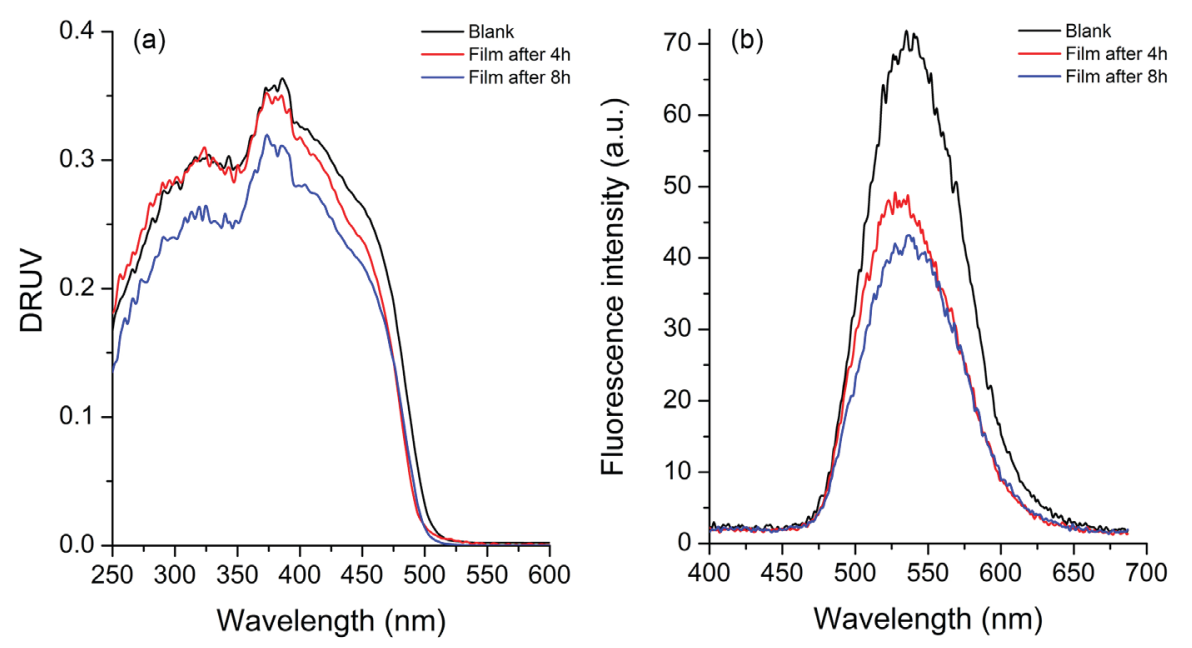

Figure 3. Photostability of compound 7 by (a) diffuse reflectance UV-Vis absorption spectra and (b) steady-state fluorescence emission.

this tetrazole presents in nitrogen atmospheres several decomposition temperatures with an initial decomposition temperature between $235-295{ }^{\circ} \mathrm{C}$ with a mass loss of 30\% and a maximum rate of decomposition at $279^{\circ} \mathrm{C}$. In an oxidizing media, a similar thermal behavior was observed, with an initial decomposition temperature between $254-294{ }^{\circ} \mathrm{C}$ with a mass loss of $12 \%$ and a maximum rate of decomposition at $280{ }^{\circ} \mathrm{C}$. These results show that the investigated compound presents significant thermal stability. In addition, its photostability was also investigated by UV-Vis and fluorescence emission spectroscopies (Figure 3). It can be observed a small decrease on the absorption intensity between $350-475 \mathrm{~nm}$. Moreover, it can also be observed a decrease on the fluorescence emission intensity after UV exposure. These preliminary results can probably be related to photobleaching process observed for 7 after UV irradiation.

\section{CD assay}

The results from the CD studies presented in Figure 4, which analyze the ability of the complex to interact with CT-DNA suggest that the complex is a weak groove binder. The complex exhibited a significant decrease in the DNA reference band at $275 \mathrm{~nm}$ that is related to base stacking without expressing changes in the $245 \mathrm{~nm}$ DNA band that is associated with right-handed helicity. A redshift is also observed for the $275 \mathrm{~nm}$ band. These observations are usually associated with a groove binding interaction mode $e^{46,52,53}$ or, in some cases, to an external interaction as can be observed in high salt concentrations associated to electrostatic binding. ${ }^{54}$ For this compound, the interaction with a DNA molecule is likely based on electrostatic interactions with the sugar-phosphate backbone, and allowed by the quadrupolar character that is present. In addition, no modification was observed when the incubations were performed in the solvent DMSO in the absence of the complex. In addition, the high molar ratios of complex and CT-DNA necessary to observe the
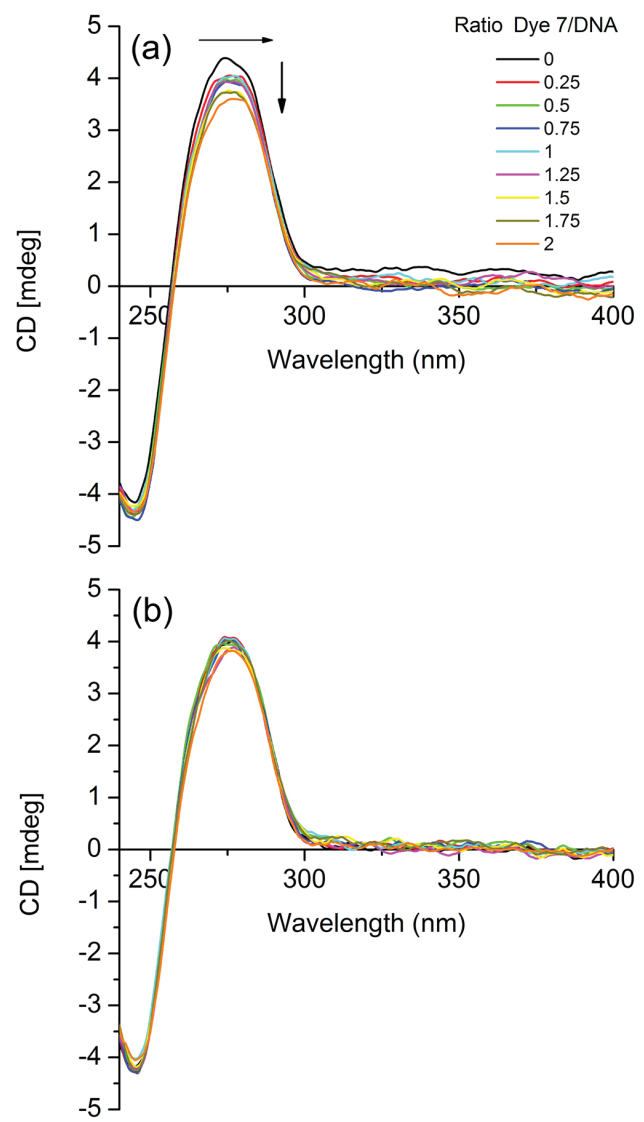

Figure 4. (a) Circular dichroism spectra of compound 7 and CT-DNA interactions showing a reduction of the DNA reference band at $275 \mathrm{~nm}$ that is related to base stacking and groove binding interactions. The redshift observed can be associated with this mode of interaction or to external binding when the $245 \mathrm{~nm}$ band does not produce any modification; (b) circular dichroism spectra of DMSO (solvent used in (a) and CT-DNA interactions showing no alteration in either the 275 or $245 \mathrm{~nm}$ bands). 
effects of the first ( $1-1$ and higher) when compared to other copper(II) complexes, ${ }^{46,53}$ characterize this complex as a weak binder.

\section{Cell viability and comet assay}

The viability test was performed in vitro using human peripheral blood to evaluate the cytotoxicity of the compounds that are included in the chemical composition of photovoltaic paints. The relevant data are summarized in Table 1. After $2 \mathrm{~h}$ of exposure, it was observed that compounds 2, 5 and $\mathbf{6}$ exhibited a significant difference relative to the negative control at the three concentrations evaluated, with the exception of compounds $\mathbf{2}$ and $\mathbf{5}$ at the highest and lowest concentrations, respectively, which did not produce a significant difference. Compound $\mathbf{5}$ resulted in lower cell viability compared to compounds $\mathbf{4}$ and $\mathbf{7}$ at the two highest concentrations, and compared to compound $\mathbf{4}$, only at the lowest concentration. In the case of compound $\mathbf{6}$ compared with compound $\mathbf{7}$, there were fewer viable cells at the highest concentration.

After $6 \mathrm{~h}$ of exposure, compounds $\mathbf{1}$ to $\mathbf{3}$ produced a lower viability at the intermediate concentration compared to the negative control, while compounds $\mathbf{2}, \mathbf{5}$ and $\mathbf{6}$ exhibited the same trend at the highest and lowest concentrations, with the exception of compound $\mathbf{2}$, which differed from the negative control only at the highest concentration tested (Table 1). Compound $\mathbf{5}$ also exhibited a significantly lower viability compared to compounds $\mathbf{4}$ and $\mathbf{7}$ at the two highest concentrations, and differed from compound 4 only at concentration 3 . After $12 \mathrm{~h}$ of exposure, a significantly lower number of viable cells were observed for compound $\mathbf{2}$ at the lowest concentration compared to the negative control and for compound $\mathbf{5}$ compared to the control group, as well as for compounds 4 and $\mathbf{7}$ at concentrations 2 and 3. Compound $\mathbf{6}$ produced similar results, but only at the highest concentration. In addition, it was observed that the highest concentration of compound $\mathbf{5}$ led to lower viability compared to the control and compound $\mathbf{7}$, while compound $\mathbf{6}$ at the intermediate concentration differed from the control and compound 4 . After $24 \mathrm{~h}$ of exposure it was observed that compounds 2 and $\mathbf{5}$ differed from the negative control at the three concentrations evaluated, while compound $\mathbf{1}$ differed only at the intermediate concentration, compound $\mathbf{3}$ at the two lowest concentrations and compound $\mathbf{6}$ only at the highest concentration. It was also noted that compound $\mathbf{5}$ led to a lower cell viability compared to compounds $\mathbf{4}$ and $\mathbf{7}$ at the three concentrations, and compound $\mathbf{6}$ only at the highest concentration.

There are three main mechanisms that induce DNA damage, as follows: (i) environmental agents (e.g., UV); (ii) products of normal metabolism, which influence the precision of the replication of genetic material and (iii) chemical, physical and biological agents, which bind to DNA and tend to lead to breakage of the molecule, ${ }^{55}$ the latter being the focus of this study. Currently, in vitro genotoxicity tests are based on established methods for the characterization of the hazards associated with chemical products. ${ }^{47,49,56,57}$ The genotoxicity evaluation of

Table 1. Effect on cell viability observed following the in vitro exposure of human peripheral blood to the intermediate and final compounds, with potential application in photovoltaic paints, obtained via a synthetic route

\begin{tabular}{|c|c|c|c|c|c|c|c|c|c|}
\hline \multirow{2}{*}{ time $/ \mathrm{h}$} & \multirow{2}{*}{ Concentration } & \multirow{2}{*}{$\begin{array}{c}\text { Negative } \\
\text { control }\end{array}$} & \multicolumn{7}{|c|}{ Compound } \\
\hline & & & 1 & 2 & 3 & 4 & 5 & 6 & 7 \\
\hline & 1 & & $85.6 \pm 1.1$ & $73.4 \pm 2.9$ & $73.2 \pm 1.5$ & $94.2 \pm 1.9$ & $39.4 \pm 0.9^{\mathrm{a}, \mathrm{c}, \mathrm{d}}$ & $40.6 \pm 0.6^{\mathrm{a}, \mathrm{d}}$ & $94.4 \pm 1.1$ \\
\hline \multirow[t]{3}{*}{2} & 2 & $100 \pm 0$ & $93.0 \pm 1.2$ & $91.4 \pm 1.3^{\mathrm{a}}$ & $93.2 \pm 1.9$ & $95.4 \pm 1.5$ & $49.6 \pm 1.1^{\mathrm{a}, \mathrm{c}, \mathrm{d}}$ & $90.0 \pm 0.7^{\mathrm{a}}$ & $94.2 \pm 0.8$ \\
\hline & 3 & & $96.8 \pm 1.3$ & $96.4 \pm 0.6^{\mathrm{a}}$ & $97.6 \pm 1.1$ & $97.8 \pm 0.8$ & $88.4 \pm 0.9^{\mathrm{a}, \mathrm{c}}$ & $97.0 \pm 0.7$ & $97.2 \pm 0.8$ \\
\hline & 1 & & $84.8 \pm 1.5$ & $68.8 \pm 1.3^{\mathrm{a}}$ & $73.8 \pm 1.3$ & $93.2 \pm 1.3$ & $37 \pm 1.2^{\mathrm{a}, \mathrm{c}, \mathrm{d} d}$ & $40.0 \pm 0.7^{\mathrm{a}}$ & $93.4 \pm 0.9$ \\
\hline \multirow[t]{3}{*}{6} & 2 & $99.6 \pm 0.55$ & $89.4 \pm 1.1^{\mathrm{a}}$ & $89.2 \pm 1.5^{\mathrm{a}}$ & $90.2 \pm 1.3^{\mathrm{a}}$ & $95.6 \pm 1.1$ & $51.4 \pm 0.9^{\mathrm{c}, \mathrm{d}}$ & $90.0 \pm 0.7$ & $93.8 \pm 0.8$ \\
\hline & 3 & & $96.2 \pm 0.8$ & $95.4 \pm 0.6$ & $95.6 \pm 1.1$ & $97.0 \pm 1.0$ & $89.0 \pm 0.7^{\mathrm{a}, \mathrm{c}}$ & $95.0 \pm 0.7^{\mathrm{a}}$ & $96.4 \pm 1.1$ \\
\hline & 1 & & $84.8 \pm 1.1$ & $69.2 \pm 0.8$ & $68.0 \pm 0.8$ & $92.2 \pm 0.8$ & $38.2 \pm 1.1^{\mathrm{a}, \mathrm{d}}$ & $37 \pm 0.7^{\mathrm{a}, \mathrm{c}, \mathrm{d}}$ & $93.0 \pm 0.7$ \\
\hline \multirow[t]{3}{*}{12} & 2 & $99.2 \pm 0.84$ & $86.2 \pm 1.8$ & $87.2 \pm 1.5$ & $86.4 \pm 0.6$ & $95.0 \pm 1.0$ & $49.4 \pm 0.9^{\mathrm{a}, \mathrm{c}, \mathrm{d}}$ & $70.0 \pm 0.7^{\mathrm{a}, \mathrm{c}}$ & $94.2 \pm 1.5$ \\
\hline & 3 & & $96.0 \pm 1.9$ & $90.2 \pm 1.1^{\mathrm{a}}$ & $91.8 \pm 1.5$ & $97.4 \pm 1.5$ & $88.4 \pm 0.9^{\mathrm{a}, \mathrm{c}, \mathrm{d}}$ & $94.0 \pm 0.7$ & $97.2 \pm 0.8$ \\
\hline & 1 & & $79.6 \pm 1.1$ & $67.4 \pm 1.5^{\mathrm{a}}$ & $71.0 \pm 1.6$ & $93.4 \pm 1.1$ & $30.2 \pm 0.8^{\mathrm{a}, \mathrm{c}, \mathrm{d}}$ & $30.0 \pm 0.7^{\mathrm{a}, \mathrm{c}, \mathrm{d}}$ & $92.0 \pm 1.6$ \\
\hline \multirow[t]{2}{*}{24} & 2 & $98 \pm 0$ & $86.0 \pm 1.0^{\mathrm{a}}$ & $85.4 \pm 1.5^{\mathrm{a}}$ & $85.2 \pm 0.8^{\mathrm{a}}$ & $96.0 \pm 0.7$ & $39.0 \pm 1.4^{\mathrm{a}, \mathrm{c}, \mathrm{d}}$ & $90.0 \pm 0.7$ & $94.2 \pm 1.5$ \\
\hline & 3 & & $95.8 \pm 0.8$ & $92.8 \pm 1.3^{\mathrm{a}}$ & $92.8 \pm 1.5^{\mathrm{a}}$ & $97.2 \pm 1.3$ & $88.2 \pm 1.6^{\mathrm{a}, \mathrm{c}, \mathrm{d}}$ & $94.0 \pm 0.7$ & $97.2 \pm 0.8$ \\
\hline
\end{tabular}

Cell viability observed following the in vitro exposure of 3 different concentrations of each compound in human peripheral blood; concentration 1 : equivalent to $2 \mathrm{mg}$ of each compound; concentration 2: equivalent to $1 \mathrm{mg}$ of each compound; concentration 3: equivalent to $0.5 \mathrm{mg}$ of each compound; values expressed as average \pm standard deviation; ${ }^{\text {a }} p<0.05$ difference compared to the negative control with the same exposure time, one-way ANOVA, Kruskal Wallis; ${ }^{\mathrm{b}} p<0.05$ difference compared to compound $\mathbf{3}$ with the same exposure time and concentration, one-way ANOVA, Kruskal Wallis; ${ }^{\mathrm{c}} p<0.05$ difference compared to compound 4 with the same exposure time and concentration, one-way ANOVA, Kruskal Wallis; ${ }^{\mathrm{d}} p<0.05$ difference compared to compound 7 with the same exposure time and concentration, one-way ANOVA, Kruskal Wallis. 
the compounds was performed using the comet assay, the results for which are the parameters of damage index and damage frequency, which are shown in Tables 2 and 3, respectively. The comet assay, also known as single-cell gel electrophoresis, is very useful and widely employed in the evaluation of DNA damage and repair in individual cells. ${ }^{58}$ The primary goal of this test is to evaluate the damage that is caused by oxidative stress, through the interaction of DNA with reactive oxygen species. ${ }^{59}$

Compound 1 exhibited a significant difference compared to the negative control after $2 \mathrm{~h}$ of exposure at concentrations 2 and 3; after $24 \mathrm{~h}$, only the highest concentration produced a difference in both parameters evaluated in the comet assay. Furthermore, at concentration 2 , after 2 and $12 \mathrm{~h}$, there was also a difference compared to the negative control; however, only for the damage index. Compound 2, on the other hand, differed significantly from the control only at the highest concentration after $2 \mathrm{~h}$ for both the DI and DF (Tables 2 and 3) while after $6 \mathrm{~h}$ of exposure, only the DI exhibited a difference from the control at the highest concentration (Table 2).

In the case of compound $\mathbf{5}$, the amount of damage was significantly greater after all exposure times at the three concentrations when compared with the negative control and compounds $\mathbf{4}$ and $\mathbf{7}$, according to both DI and DF. However, with the exception that at the three concentrations after $2 \mathrm{~h}$ of exposure, no difference was observed compared to compound 4, both damage parameters at the lowest concentration differed only from the negative control and compound 3 (Tables 2 and 3). Additionally, after $6 \mathrm{~h}$ of exposure at the intermediate concentration, the DF and DI demonstrated no difference compared to compound $\mathbf{4}$, but the DI differed from compound $\mathbf{3}$.

In comparison with concentrations 2 and 3 after $12 \mathrm{~h}$, the DI exhibited no difference from compound 4 (Tables 2 and 3), and the DF values after $12 \mathrm{~h}$ at the same concentrations also produced no significant differences. In addition, at concentration 3 after $24 \mathrm{~h}$, no difference was detected in relation to compound $\mathbf{4}$ was detected (Table 3 ).

For compound 6, both the DI and the DF produced significant differences at all concentrations after the four exposure times compared to the negative control (Tables 2 and 3). However, after $24 \mathrm{~h}$ of exposure at the lowest concentration, no differences were found for the DF compared to the control. At concentration 1 after $6 \mathrm{~h}$ of exposure, the DI and DF were significantly higher than at concentration 3 , and at the same concentration after $24 \mathrm{~h}$, this behavior was observed only for the DI (Tables 2 and 3). At concentrations 2 and 3 after $12 \mathrm{~h}$ and at concentration 2 after $24 \mathrm{~h}$ there was a significant difference in the DI and DF compared to compound 7, while only the DF at concentration 1 after $24 \mathrm{~h}$ differed from compound 7 (Tables 2 and 3). Compound 7 did not produce significantly greater damage in the cell viability test and comet assay compared to the other compounds that are included in the chemical composition of the paint, demonstrating that it does not have toxic or genotoxic activity (Tables 1, 2 and 3).

On the other hand, only compounds $\mathbf{1}$ and $\mathbf{4}$ promote reactions with biological substrates that can damage

Table 2. Effect of in vitro exposure of human peripheral blood to intermediate and final compounds, with potential application in photovoltaic paints, obtained synthetically, on the damage index (DI) obtained in the comet assay

\begin{tabular}{|c|c|c|c|c|c|c|c|c|c|}
\hline \multirow{2}{*}{ time / $\mathrm{h}$} & \multirow{2}{*}{ Concentration } & \multirow{2}{*}{$\begin{array}{c}\text { Negative } \\
\text { control }\end{array}$} & \multicolumn{7}{|c|}{ Compound } \\
\hline & & & 1 & 2 & 3 & 4 & 5 & 6 & 7 \\
\hline & 1 & & $51.2 \pm 14.4$ & $86.6 \pm 15.7^{\mathrm{a}}$ & $45.8 \pm 12.5$ & $61.8 \pm 41.1$ & $321.4 \pm 26.5^{\mathrm{a}, \mathrm{d}}$ & $184.4 \pm 25.5^{\mathrm{a}}$ & $42.6 \pm 19.4$ \\
\hline \multirow[t]{3}{*}{2} & 2 & $6.8 \pm 3.7$ & $68.8 \pm 12.7^{\mathrm{a}}$ & $30.6 \pm 9.6$ & $36.6 \pm 15.5$ & $54.2 \pm 26.0$ & $252.6 \pm 57.2^{\mathrm{a}, \mathrm{d}}$ & $137.0 \pm 13.3^{\mathrm{a}}$ & $24.8 \pm 11.1$ \\
\hline & 3 & & $34.2 \pm 10.8$ & $25.4 \pm 6.0$ & $20.6 \pm 8.2$ & $37.4 \pm 23.5$ & $160.4 \pm 34.7^{\mathrm{a}, \mathrm{b}}$ & $111.8 \pm 7.1^{\mathrm{a}}$ & $22.2 \pm 3.3$ \\
\hline & 1 & & $77.4 \pm 13.4$ & $86.8 \pm 16.2^{\mathrm{a}}$ & $56.4 \pm 15.8$ & $32.2 \pm 9.7$ & $335.0 \pm 8.4^{\mathrm{a}, \mathrm{c}, \mathrm{d}}$ & $143.8 \pm 30.2^{\mathrm{a}, \mathrm{c}}$ & $46.2 \pm 3.8$ \\
\hline \multirow[t]{3}{*}{6} & 2 & $10.2 \pm 2.4$ & $64.0 \pm 14.5^{\mathrm{a}}$ & $39.2 \pm 10.7$ & $33.6 \pm 18.3$ & $36.6 \pm 12.9$ & $283.6 \pm 14.5^{\mathrm{a}, \mathrm{b}, \mathrm{d}}$ & $108.0 \pm 18.0^{\mathrm{a}}$ & $28.6 \pm 9.9$ \\
\hline & 3 & & $56.0 \pm 11.0^{\mathrm{a}}$ & $33.4 \pm 8.9$ & $23.4 \pm 4.4$ & $23.8 \pm 14.3$ & $183.2 \pm 15.8^{\mathrm{a}, \mathrm{c}, \mathrm{d}}$ & $91.6 \pm 11.5^{\mathrm{a}}$ & $21.4 \pm 8.6$ \\
\hline & 1 & & $94.4 \pm 20.2$ & $110.6 \pm 50.1$ & $59.4 \pm 5.4$ & $48.4 \pm 51.4$ & $337.5 \pm 24.7^{\mathrm{a}, \mathrm{c}, \mathrm{d}}$ & $158.8 \pm 12.8^{\mathrm{a}}$ & $42.2 \pm 17.9$ \\
\hline \multirow[t]{3}{*}{12} & 2 & $12.2 \pm 1.1$ & $72.2 \pm 19.0^{\mathrm{a}}$ & $46.4 \pm 22.5$ & $38.2 \pm 4.3$ & $31.8 \pm 19.2$ & $282.4 \pm 10.5^{\mathrm{a,d}}$ & $109.0 \pm 12.9^{\mathrm{a}, \mathrm{d}}$ & $19.8 \pm 2.9$ \\
\hline & 3 & & $51.6 \pm 11.9$ & $41.4 \pm 13.5$ & $31.8 \pm 12.2$ & $32.8 \pm 24.4$ & $101.5 \pm 7.8^{\mathrm{a}, \mathrm{d}}$ & $85.8 \pm 13.7^{\mathrm{a}, \mathrm{d}}$ & $16.4 \pm 4.8$ \\
\hline & 1 & & $80.6 \pm 6.5^{\mathrm{a}}$ & $62.4 \pm 13.7$ & $42.0 \pm 5.6$ & $36.2 \pm 14.1$ & $323.6 \pm 25.0^{\mathrm{a}, \mathrm{c}, \mathrm{d}}$ & $190.8 \pm 24.3^{\mathrm{a}, \mathrm{c}}$ & $21.8 \pm 1.5$ \\
\hline \multirow[t]{2}{*}{24} & 2 & $12.0 \pm 2.8$ & $58.2 \pm 11.9$ & $57.0 \pm 8.4$ & $33.6 \pm 5.7$ & $23.8 \pm 8.7$ & $283.0 \pm 9.2^{\mathrm{a}, \mathrm{c}, \mathrm{d}}$ & $102.3 \pm 17.8^{\mathrm{a}, \mathrm{d}}$ & $13.4 \pm 7.6$ \\
\hline & 3 & & $56.2 \pm 14.9$ & $28.2 \pm 8.4$ & $24.8 \pm 6.5$ & $24.8 \pm 16.8$ & $146.2 \pm 28.0^{\mathrm{a}, \mathrm{d}}$ & $64.0 \pm 11.2^{\mathrm{a}}$ & $13.0 \pm 10.0$ \\
\hline
\end{tabular}

Cell viability observed following the in vitro exposure of 3 different concentrations of each compound in human peripheral blood; concentration 1: equivalent to $2 \mathrm{mg}$ of each compound; concentration 2: equivalent to $1 \mathrm{mg}$ of each compound; concentration 3: equivalent to $0.5 \mathrm{mg}$ of each compound; values expressed as average \pm standard deviation; ${ }^{a} p<0.05$ difference compared to the negative control with the same exposure time, one-way ANOVA, Kruskal Wallis; ${ }^{\mathrm{b}} p<0.05$ difference compared to compound $\mathbf{3}$ with the same exposure time and concentration, one-way ANOVA, Kruskal Wallis; ${ }^{\mathrm{c}} p<0.05$ difference compared to compound $\mathbf{4}$ with the same exposure time and concentration, one-way ANOVA, Kruskal Wallis; ${ }^{\mathrm{d}} p<0.05$ difference compared to compound 7 with the same exposure time and concentration, one-way ANOVA, Kruskal Wallis. 
Table 3. Effect of in vitro exposure of human peripheral blood to intermediate and final compounds, with potential application in photovoltaic paints, obtained synthetically, on the damage frequency (DF) obtained in the comet assay

\begin{tabular}{|c|c|c|c|c|c|c|c|c|c|}
\hline \multirow{2}{*}{ time / $\mathrm{h}$} & \multirow{2}{*}{ Concentration } & \multirow{2}{*}{$\begin{array}{c}\text { Negative } \\
\text { control }\end{array}$} & \multicolumn{7}{|c|}{ Compound } \\
\hline & & & 1 & 2 & 3 & 4 & 5 & 6 & 7 \\
\hline & 1 & & $17.0 \pm 4.9$ & $26.8 \pm 5.0^{\mathrm{a}}$ & $16.4 \pm 3.7$ & $19.4 \pm 9.9$ & $87.2 \pm 5.8^{\mathrm{a}, \mathrm{d}}$ & $50.0 \pm 6.4^{\mathrm{a}}$ & $13.2 \pm 4.6$ \\
\hline \multirow[t]{3}{*}{2} & 2 & $4.8 \pm 2.49$ & $19.2 \pm 5.9$ & $13.2 \pm 4.8$ & $12.4 \pm 4.2$ & $17.6 \pm 6.1$ & $76.8 \pm 9.4^{\mathrm{a}, \mathrm{d}}$ & $40.0 \pm 2.3^{\mathrm{a}}$ & $9.2 \pm 2.4$ \\
\hline & 3 & & $13.4 \pm 3.4$ & $12.0 \pm 2.1$ & $7.2 \pm 3.3$ & $13.8 \pm 4.6$ & $46.6 \pm 9.6^{\mathrm{a}, \mathrm{b}}$ & $34.8 \pm 3.3^{\mathrm{a}, \mathrm{b}}$ & $10.6 \pm 2.6$ \\
\hline & 1 & & $25.2 \pm 3.7$ & $26.6 \pm 4.8$ & $20.2 \pm 4.3$ & $12.0 \pm 2.7$ & $88.2 \pm 1.7^{\mathrm{a}, \mathrm{c}, \mathrm{d}}$ & $40.6 \pm 7.9^{\mathrm{a}, \mathrm{c}}$ & $15.6 \pm 1.7$ \\
\hline \multirow[t]{3}{*}{6} & 2 & $6.2 \pm 1.30$ & $25.4 \pm 5.5^{\mathrm{a}}$ & $14.4 \pm 4.6$ & $12.4 \pm 4.0$ & $13.4 \pm 3.5$ & $77.0 \pm 7.9^{\mathrm{a}, \mathrm{d}}$ & $31.0 \pm 5.2^{\mathrm{a}}$ & $10.2 \pm 3.0$ \\
\hline & 3 & & $21.2 \pm 4.6^{\mathrm{a}}$ & $14.6 \pm 2.6$ & $8.6 \pm 1.5$ & $9.8 \pm 3.6$ & $50.2 \pm 4.7^{\mathrm{a}, \mathrm{b}, \mathrm{c}, \mathrm{d}}$ & $27.0 \pm 3.3^{\mathrm{a}}$ & $9.2 \pm 3.0$ \\
\hline & 1 & & $30.2 \pm 4.6$ & $31.8 \pm 13.1$ & $20.4 \pm 2.1$ & $14.4 \pm 12.1$ & $88.5 \pm 4.0^{\mathrm{a}, \mathrm{c}, \mathrm{d}}$ & $43.4 \pm 3.0^{\mathrm{a}}$ & $14.4 \pm 5.2$ \\
\hline \multirow[t]{3}{*}{12} & 2 & $6.6 \pm 0.55$ & $24.4 \pm 5.5$ & $16.2 \pm 6.1$ & $13.0 \pm 1.2$ & $11.2 \pm 6.7$ & $75.4 \pm 1.8^{\mathrm{a}, \mathrm{c}, \mathrm{d}}$ & $31.0 \pm 3.4^{\mathrm{a}, \mathrm{d}}$ & $7.8 \pm 1.9$ \\
\hline & 3 & & $18.8 \pm 5.6$ & $13.2 \pm 3.2$ & $10.6 \pm 3.4$ & $10.6 \pm 5.6$ & $29.8 \pm 2.1^{\mathrm{a}, \mathrm{d}}$ & $25.2 \pm 3.5^{\mathrm{a}, \mathrm{d}}$ & $7.0 \pm 1.4$ \\
\hline & 1 & & $25.0 \pm 1.6^{\mathrm{a}}$ & $22.4 \pm 5.0$ & $17.2 \pm 3.5$ & $12.4 \pm 3.0$ & $84.8 \pm 4.7^{\mathrm{a}, \mathrm{c}, \mathrm{d}}$ & $53.2 \pm 4.0^{\mathrm{a}, \mathrm{d}}$ & $10.4 \pm 2.3$ \\
\hline \multirow[t]{2}{*}{24} & 2 & $6.6 \pm 0.89$ & $25.6 \pm 15.1$ & $19.0 \pm 3.5$ & $11.0 \pm 2.2$ & $9.6 \pm 3.5$ & $74.2 \pm 2.3^{\mathrm{a}, \mathrm{c}, \mathrm{d}}$ & $30.5 \pm 6.2^{\mathrm{a}, \mathrm{d}}$ & $6.2 \pm 1.8$ \\
\hline & 3 & & $17.8 \pm 4.7$ & $11.6 \pm 3.8$ & $10.6 \pm 3.9$ & $9.8 \pm 3.6$ & $41.6 \pm 6.4^{\mathrm{a}, \mathrm{c}, \mathrm{d}}$ & $20.2 \pm 5.0$ & $8.0 \pm 5.2$ \\
\hline
\end{tabular}

Cell viability observed following the in vitro exposure of 3 different concentrations of each compound in human peripheral blood; concentration 1 : equivalent to $2 \mathrm{mg}$ of each compound; concentration 2: equivalent to $1 \mathrm{mg}$ of each compound; concentration 3: equivalent to $0.5 \mathrm{mg}$ of each compound; values expressed as average \pm standard deviation; ${ }^{\text {a }} p<0.05$ difference compared to the negative control with the same exposure time, one-way ANOVA, Kruskal Wallis; ${ }^{\mathrm{b}} p<0.05$ difference compared to compound $\mathbf{3}$ with the same exposure time and concentration, one-way ANOVA, Kruskal Wallis; ${ }^{\mathrm{c}} p<0.05$ difference compared to compound $\mathbf{4}$ with the same exposure time and concentration, one-way ANOVA, Kruskal Wallis; ${ }^{\mathrm{d}} p<0.05$ difference compared to compound 7 with the same exposure time and concentration, one-way ANOVA, Kruskal Wallis.

biomolecules and consequently affect human health. The most serious effects are from damage to DNA and ribonucleic acid (RNA). If the DNA chain is broken, it can be reconnected at another position, thus altering the order of its bases. This is one of the basic processes involved in mutation, and the accumulation of damaged bases can initiate oncogenesis. The results of this study highlight the importance of considering a compound's concentration and exposure time when evaluating their genotoxicity, particularly those that are obtained early in the synthetic route. An increase in the compound's concentration is directly proportional to the increase in the damage, and inversely proportional to cell viability; that is, the higher the concentration of the sample is, the lower the cell viability and the greater the DNA damage will be.

There are several factors that could lead to variations in the damage indicated by the present results in both cell viability and the comet assay. It was observed that compounds $\mathbf{5}$ and $\mathbf{6}$ led to greater damage to the genetic material than did the final compound. Compounds $\mathbf{1}, \mathbf{2}$ and 6 contain in their chemical structures an electronegative moiety (bromine) despite the benzothiadiazole group in the final compound 7. The presence of a bromine substituent in these compounds increases the possibility that a tautomeric change will occur. If 5-bromouracil (5-BU) is incorporated in place of thymine and a tautomeric change to the enol form occurs, the 5-BU will pair with guanine which, after a round of replication, will result in a transition of $\mathrm{A}=\mathrm{T}$ to $\mathrm{G}=\mathrm{C}$. In addition, the presence of 5-BU in DNA increases the sensitivity of the molecule to UV light, which is itself mutagenic. Bromine has been shown to be carcinogenic in rats, hamsters and mice. ${ }^{48,60-63}$ Additionally, its mutagenic effects in several in vitro ${ }^{64-66}$ and in vivo ${ }^{67,68}$ test systems have been verified. The mechanisms underlying the genotoxicity of bromine are only partially understood. Thus, it is important to evaluate the genotoxic action of compounds that are used in the production of photovoltaic paint.

Figure 5 shows the data for the cell viability and the DNA damage index and damage frequency obtained in vitro for blood cells that are exposed to the final (D- $\pi-A-\pi-D)$ photoactive compound synthesized according to Scheme 1. The cell viability was not significantly different for the exposure times tested at any of the concentrations of the photoactive benzothiadiazole dye.

With regard to the damage index, at concentration 1 after 2, 6 and $24 \mathrm{~h}$ of exposure, the DI resulted in a significant difference compared to the negative control and compared to the values obtained for concentrations 2 and 3 after 2, 6 and $12 \mathrm{~h}$ of exposure. Additionally, for exposure times of 2, 6 and $12 \mathrm{~h}$, the DI differed statistically from the value obtained at $24 \mathrm{~h}$ at the highest concentration (concentration 1). For $2 \mathrm{~h}$ of exposure, the DI values obtained at concentrations 2 and 3 differed from the negative control, while after $6 \mathrm{~h}$, 
only the DI obtained at concentration 2 differed from the negative control. The DI for an exposure time of $6 \mathrm{~h}$ exhibited a statistically significant difference compared to that obtained after $24 \mathrm{~h}$ at concentration 2 .

In the case of the DF parameter that was evaluated in the comet assay, the highest concentration after the first three exposure times demonstrated significantly greater damage compared to the negative control, from which the results for concentration 2 after 2 and $6 \mathrm{~h}$ of exposure also differed, and for those for concentration 3 after 6 and $12 \mathrm{~h}$ of exposure. After $24 \mathrm{~h}$ of exposure, no significant differences were observed for any of concentrations evaluated compared to the DI or the DF, showing that within this period, this

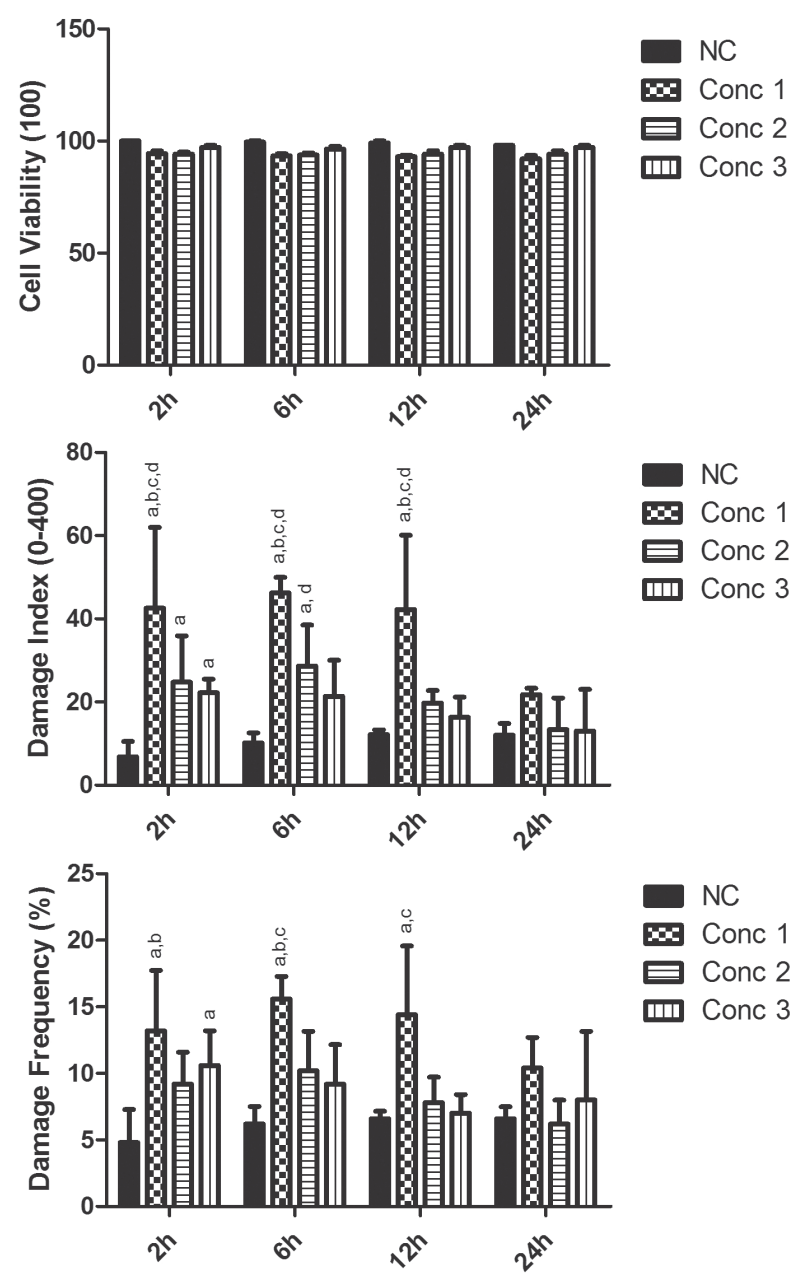

Figure 5. Cell viability (top) and the DNA damage index (middle) and damage frequency (bottom) obtained in vitro for blood cells exposed to compound 7 at three concentrations (conc. 1-3: 2, 1 and $0.5 \mathrm{mg}$ of $\mathbf{7}$, respectively) and for four exposure times obtained using the comet assay. Data are expressed as average \pm standard deviation. ${ }^{a} p<0.05$ difference compared to the negative control, with the same exposure time, twoway ANOVA 2, post hoc Bonferroni; ${ }^{b} p<0.05$ difference compared to concentration 2, with the same exposure time and concentration, two-way ANOVA 2, post hoc Bonferroni; ${ }^{c} p<0.05$ difference compared to concentration 3, with the same exposure time and concentration, two-way ANOVA 2, post hoc Bonferroni; ${ }^{\mathrm{d}} p<0.05$ difference compared to $24 \mathrm{~h}$ of exposure at the same concentration, two-way ANOVA, post hoc Bonferroni. compound did not produce genotoxicity at any of the concentrations tested.

Figure 6 reports the results for compounds $\mathbf{1}$ and $\mathbf{5}$, which begin the series in the synthetic route, together with compound 7, which is the final product, i.e., the photoactive (D- $\pi$-A- $\pi$-D) benzothiadiazole derivative with potential application in photovoltaic paints. This figure shows that from the cell viability and the parameters evaluated in the comet assay, as the compounds pass through the synthetic route they lose toxicity, with the final compound 7 exhibiting no sign of toxicity.

The results of this study show that blood samples in contact with compound 7 remain viable, exhibiting no significant difference compared to the negative control, and the DI and DF were of minimal significance, even at the highest concentration of the compound. It is worth mentioning that at the lowest concentration, no cytotoxic effect was observed.
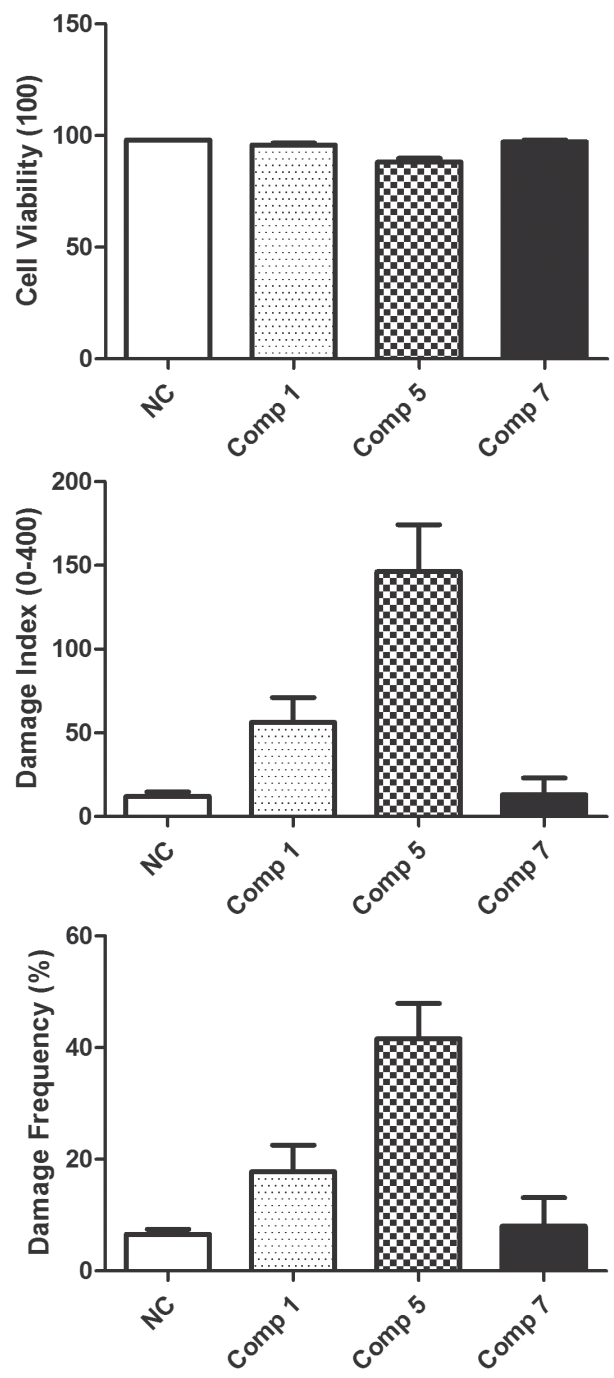

Figure 6. Comparison of the parameters obtained for the final compound 7 and respective precursors $\mathbf{1}$ and $\mathbf{5}$. 
In addition, there was almost no genotoxic damage to the exposed cells, even though concentration 3 is much higher than that used in paint compositions. Although the initial compounds were found to be extremely damaging to DNA, the results of cell viability and comet assay demonstrate that the final compound $\mathbf{7}$ is almost inert to the genetic material. Although epidemiological studies have demonstrated the role of environmental factors in a wide range of human carcinomas, the exact mechanisms by which environmental exposure leads to the development and progression of cancer remain poorly understood. It is only with recent advances in the area of genome studies that the molecular mechanisms associated with environmental influences are beginning to unfold. One of the main problems related to the interpretation of studies on biomonitoring is estimating the degree of exposure. Possible abuse or inappropriate use can lead to significant levels of exposure. ${ }^{69}$

\section{Conclusions}

A $\pi$-conjugated quadrupolar compound (D- $\pi-A-\pi-D)$ with potential applications in optoelectronic devices and as dyes in photovoltaic paints was synthesized with a good yield and was fully characterized. The ability of the obtained compound to interact with CT-DNA was characterized using circular dichroism analysis, which produced positive results. Once it was determined that an interaction occurs, the compound and respective intermediates were evaluated in vitro at three different concentrations and four exposure times using the comet assay. It was demonstrated that the final compound does not decrease cell viability or damage DNA according to the damage index and damage frequency that were obtained in in vitro tests on blood cells. Thus, it can be concluded that this new fluorophore does not produce toxicity. The same was demonstrated for the intermediate compounds, as no toxic or genotoxic activity was observed. These results indicate that the intermediate compounds, as well as the fluorophore containing the 2,1,3-benzothiadiazole unit with alkylated tetrazole terminal groups, can be used safely in synthetic processes and in manufacturing as a dye for paints, photovoltaic devices, OLEDs and other functional materials.

\section{Acknowledgments}

The authors would like to thank Fundação de Amparo à Pesquisa do Estado do Rio Grande do Sul (FAPERGS), Usina Hidrelétrica Barra Grande (BAESA), Campos Novos Energia S.A. (Enercam) and Serra do Facão Energia S.A. (Sefac) for their financial support; and CEBIME-UFSC for the circular dichroism measurements.

\section{References}

1. Yun, D. H.; Yoo, H. S.; Heo, S. W.; Song, H. J.; Moon, D. K.; Woo, J. W.; Park, Y. S.; J. Ind. Eng. Chem. 2013, 19, 421.

2. Liu, Y.; Lai, H.; Zhong, H.; Xu, E.; Du, J.; Li, Y.; Fang, Q.; Tetrahedron Lett. 2010, 51, 4462.

3. He, Q.; He, C.; Sun, Y.; Wu, H.; Li, Y.; Bai, F.; Thin Solid Films 2008, 516, 5935.

4. Lee, J. Y.; Kim, S. H.; Song, I. S.; Moon, D. K.; J. Mater. Chem. 2011, 21, 16480.

5. Lee, J. Y.; Song, K. W.; Song, H. J.; Moon, D. K.; Synth. Met. 2011, 161, 2434.

6. Lee, J. Y.; Song, K. W.; Ku, J. R.; Sung, T. H.; Moon, D. K.; Sol. Energy Mater. Sol. Cells 2011, 95, 3377.

7. Li, Y.; Zou, Y.; Adv. Mater. 2008, 20, 2952.

8. Li, Y.; Xue, L.; Li, H.; Li, Z.; Xu, B.; Wen, S.; Tian, W.; Macromolecules 2009, 42, 4491.

9. Song, I. S.; Heo, S. W.; Lee, J. Y.; Moon, D. K.; J. Ind. Eng. Chem. 2011, 17, 651.

10. Song, H. J.; Lee, S. M.; Lee, J. Y.; Choi, B. H.; Moon, D. K.; Synth. Met. 2011, 161, 2451.

11. Song, H. J.; Lee, J. Y.; Song, I. S.; Moon, D. K.; Haw, J. R.; J. Ind. Eng. Chem. 2011, 17, 352.

12. Yamada, S.; Park, S.; Song, S.; Heo, M.; Shim, J. Y.; Jin, Y.; Kim, I.; Lee, H.; Lee, K.; Yoshinaga, K.; Kim, J. Y.; Suh, H.; Polymer 2010, 51, 6174.

13. Park, M. J.; Lee, J.; Park, J. H.; Lee, S. K.; Lee, J. I.; Chu, H. Y.; Hwang, D. H.; Shim, H. K.; Macromolecules 2008, 41, 3063.

14. Jung, M. S.; Shin, W.; Park, S. J.; You, H.; Park, J. B.; Suh, H.; Lim, Y.; Yoon, D. Y.; Kim, J. H.; Synth. Met. 2009, 159, 1928.

15. Zou, Y.; Wu, W.; Sang, G.; Yang, Y.; Liu, Y.; Li, Y.; Macromolecules 2007, 40, 7231.

16. Mondal, R.; Becerril, H. A.; Verploegen, E.; Kim, D.; Norton, J. E.; Ko, S.; Miyaki, N.; Lee, S.; Toney, M. F.; Brédas, J. L.; McGehee, M. D.; Bao, Z.; J. Mater. Chem. 2010, 20, 5823.

17. Kim, C. G.; Quinn, J. R.; Facchetti, A.; Marks, T. J.; Adv. Mater. 2010, 22, 342.

18. Anant, P.; Mangold, H.; Lucas, N. T.; Laquai, F.; Jacob, J.; Polymer 2011, 52, 4442.

19. Peng, Q.; Liu, X.; Su, D.; Fu, G.; Xu, J.; Dai, L.; Adv. Mater. 2011, 23, 4554.

20. Zhang, G.; Yang, G.; Yan, H.; Kim, J. H.; Ade, H.; Wu, W.; Xu, X.; Duan, Y.; Peng, Q.; Adv. Mater. 2017, 29, 1606054.

21. Higashihara, T.; Saito, Y.; Mizoguchi, K.; Ueda, M.; React. Funct. Polym. 2013, 73, 303.

22. Vieira, A. A.; Cristiano, R.; Bortoluzzi, A. J.; Gallardo, H. J.; J. Mol. Struct. 2008, 875, 364.

23. Tao, Y. M.; Li, H. Y.; Xu, Q. L.; Zhu, Y. C.; Kang, L. C.; Zheng, Y. X.; Zuo, J. L.; You, X. Z.; Synth. Met. 2011, 161, 718.

24. Silvestri, F.; Marrocchi, A.; Seri, M.; Kim, C.; Marks, T. J.; Facchetti, A.; Taticchi, A.; J. Am. Chem. Soc. 2010, 132, 6108. 
25. Neto, B. A. D.; Carvalho, P. H. P. R.; Correa, J. R.; Acc. Chem. Res. 2015, 48, 1560.

26. Wałęsa-Chorab, M.; Tremblay, M. H.; Ettaoussi, M.; Skene, W. G.; Pure Appl. Chem. 2015, 87, 649.

27. Bolisetty, M. N. K. P.; Li, C. T.; Thomas, K. R. J.; Bodedla, G. B.; Ho, K. C.; Tetrahedron 2015, 71, 4203.

28. Gautam, P.; Maragani, R.; Misra, R.; RSC Adv. 2015, 5, 18288.

29. Ishi-i, T.; Kitahara, I.; Yamada, S.; Sanada, Y.; Sakurai, K.; Tanaka, A.; Hasebe, N.; Yoshihara, T.; Tobita, S.; Org. Biomol. Chem. 2015, 13, 1818.

30. Lee, J. Y.; Heo, S. W.; Choi, H.; Kwon, Y. J.; Haw, J. R.; Moon, D. K.; Sol. Energy Mater. Sol. Cells 2009, 93, 1932.

31. Kraft, A.; Grimsdale, A. C.; Holmes, A. B.; Angew. Chem., Int. Ed. 1998, 37, 402.

32. He, Q.; Sun, Y.; Liu, W.; Xu, S.; Cao, Z.; Cheng, J.; Bai, F.; Tetrahedron Lett. 2007, 48, 4249.

33. Pitarque, M.; Vaglenov, A.; Nosko, M.; Hirvonen, A.; Norppa, H.; Creus, A.; Marcos, R.; Mutat. Res. 1999, 441, 115.

34. Suzuki, T.; Yanagiba, Y.; Suda, M.; Wang, R. S.; J. Occup. Health 2014, 56, 205.

35. Karihtala, P.; Soini, Y.; Vaskivuo, L.; Bloigu, R.; Puistola, U.; Int. J. Gynecol. Cancer 2009, 19, 1047.

36. Snatzke, G. In Circular Dichroism: Principles and Applications, $2^{\text {nd }}$ ed.; Berova, N.; Nakanishi, K.; Woody, R. W., eds.; WileyVCH: New York, 2000, ch. 1.

37. Aksoy, H.; Yilmaz, S.; Celik, M.; Yüzbaşioglu, D.; Unal, F.; J. Appl. Toxicol. 2006, 26, 10.

38. Rekhadevi, P. V.; Mahboob, M.; Rahman, M. F.; Grover, P.; Environ. Mol. Mutagen. 2011, 52, 310.

39. Cassini, C.; Calloni, C.; Bortolini, G.; Garcia, S. C.; Dornelles, M. A.; Henriques, J. A.; Erdtmann, B.; Salvador, M.; Int. J. Occup. Med. 2011, 24, 308.

40. Farbairn, D. W.; Olive, P. L.; O’Neill, K. L.; Mutat. Res. 1995, 339, 37.

41. McAteer, J. A.; Davis, J. In Basic Cell Culture A Practical Approach; Davis, J. M., ed.; Oxford University Press: New York, 1994, p. 93-148.

42. Armarego W. L. F.; Chai, C. L. L.; Purification of Laboratory Chemicals, 5 $^{\text {th }}$ ed.; Elsevier Academic Press: Cornwall, UK, 2003.

43. Santos, D. R.; Oliveira, A. G. S.; Coelho, R. L.; Begnini, I. M.; Magnago, R. F.; da Silva, L.; ARKIVOC 2008, 17, 157.

44. Akhlaghinia, B.; Rezazadeh, S.; J. Braz. Chem. Soc. 2012, 23, 2197.

45. da Silveira Neto, B. A.; Lopes, A. S.; Ebeling, G.; Gonçalves, R. S.; Costa, V. E. U.; Quina, F. H.; Dupont, J.; Tetrahedron 2005, 61, 10975.

46. Bortolotto, T.; Silva, P. P.; Neves, A.; Pereira-Maia, E. C.; Terenzi, H.; Inorg. Chem. 2011, 50, 10519.

47. Warheit, D. B.; Donner, E. M.; Nanotoxicology 2010, 4, 409.
48. Tice, R. R.; Agurell, E.; Anderson, D.; Burlinson, B.; Hartmann, A.; Kobayashi, H.; Miyamae, Y.; Rojas, E.; Ryu, J. C.; Sasaki, Y. F.; Environ. Mol. Mutagen. 2000, 35, 206.

49. Landsiedel, R.; Ma-Hock, L.; Ravenzwaay, B. V.; Schulz, M.; Wiench, K.; Champ, S.; Shulte, S.; Wohlleben, W.; Oesch, F.; Nanotoxicology 2010, 4, 364.

50. https://www.graphpad.com/, accessed in December 2017.

51. Westrup, J. L.; Oenning, L. W.; Paula, M. M. S.; Duarte, R. C.; Rodembusch, F. S.; Frizon, T. E. A.; da Silva, L.; Dal-Bó, A. G.; Dyes Pigm. 2016, 126, 209.

52. Dhar, S.; Nethaji, M.; Chakravarty, A. R.; J. Inorg. Biochem. 2005, 99, 805 .

53. Bortolotto, T.; Silva-Caldeira, P. P.; Pich, C. T.; Pereira-Maia, E. C.; Terenzi, H.; Chem. Commun. 2016, 52, 7130.

54. Kypr, J.; Kejnovská, I.; Renčiuk, D.; Vorlíčková, M.; Nucleic Acids Res. 2009, 37, 1713.

55. Hoeijmakers, J. H. J.; Nature 2001, 411, 366.

56. Donner, M.; Tran, L.; Muller, J.; Vrijhof, H.; Nanotoxicology 2010, 4, 345.

57. Fubini, B.; Ghiazza, M.; Fenoglio, I.; Nanotoxicology 2010, 4, 347.

58. Brianezi, G.; de Camargo, J. V. L.; Miot, H. A.; J. Bras. Patol. Med. Lab. 2009, 45, 325.

59. Shaposhnikov, S.; Azqueta, A.; Henriksson, S.; Meier, S.; Gaivão, I.; Huskisson, N. H.; Smart, A.; Brunborg, G.; Nilsson, M.; Collins, A. R.; Toxicol. Lett. 2010, 195, 31.

60. Kurokawa, Y.; Maekawa, A.; Takahashi, M.; Hayashi, Y.; Environ. Health Perspect. 1990, 87, 309.

61. DeAngelo, A. B.; George, M. H.; Kilburn, S. R.; Moore, T. M.; Wolf, D. C.; Toxicol. Pathol. 1998, 26, 587.

62. Wolf, D. C.; Crosby, L. M.; George, M. H.; Kilburn, S. R.; Moore, T. M.; Miller, R. T.; DeAngelo, A. B.; Toxicol. Pathol. 1998, 26, 724.

63. Umemura, T.; Sai, K.; Takagi, A.; Hasegawa, R.; Kurokawa, Y.; Carcinogenesis 1995, 16, 593.

64. Ishidate Jr., M.; Sofuni, T.; Yoshikawa, K.; Hayashi, M.; Nohmi, T.; Sawada, M.; Matsuoka, A.; Food Chem. Toxicol. 1984, 22, 623.

65. Speit, G.; Haupter, S.; Schutz, P.; Kreis, P.; Mutat. Res. 1999, 439, 213.

66. Harrington-Brock, K.; Collard, D. D.; Chen, T.; Mutat. Res. 2003, 537, 21.

67. Arai, T.; Kelly, V. P.; Minowa, O.; Noda, T.; Nishimura, S.; Carcinogenesis 2002, 23, 2005.

68. Arai, T.; Kelly, V. P.; Komoro, K.; Minowa, O.; Noda, T.; Nishimura, S.; Cancer Res. 2003, 63, 4287.

69. Bolognesi, C.; Mutat Res. 2003, 543, 251.

Submitted: October 13, 2017

Published online: December 21, 2017 